\title{
MONTESA Y LA CRISIS DEL SIGLO XVII: EL COLAPSO FINANCIERO DE LA ORDEN MILITAR VALENCIANA ${ }^{1}$
}

\author{
Fernando ANDRÉs ROBRES \\ Universidad Autónoma de Madrid
}

\begin{abstract}
Resumen
El artículo constata, desde documentación original, la brusca caída de la renta del señorío de la Orden de Montesa (maestrazgo y encomiendas) en el siglo XVII. Como, sin embargo, el gasto no pudo ser contenido a tiempo, la institución conoció una situación límite, de lo que se ofrecen testimonios. Para intentar paliarla fueron a veces propuestas medidas extremas, no siempre viables en la práctica.

Palabras clave: órdenes militares, Orden de Montesa, Reino de Valencia, nobleza, crisis del siglo XVII.
\end{abstract}

\begin{abstract}
The article describes, from original documentation, the sudden fall in the income of the Order of Montesa in the seventeenth century. The inability of the military order of the Kingdom of Valencia to decrease its expenses led to an increasingly critical economic situation. While some of its members suggested extreme measures to solve the crisis, few of these proved practical.

Key words: Monastic-military Orders, Order of Montesa, Kingdom of Valencia, Nobility, General Crisis of the Seventeenth Century.
\end{abstract}

1. Este trabajo se enmarca en el Proyecto de Investigación Elites de poder y relaciones sociales en la Valencia Moderna (BHA2002-01075), financiado por el Plan Nacional de Investigación Científica, Desarrollo e Investigación Tecnológica. 
Por la inclemencia de los tiempos, guerras y contagios se ha reducido a la tercera parte de las rentas que tenían los maestres, pues llegando a veinte mil ducados de plata, no pasan oy de siete $\mathrm{mil}^{2}$.

Anónimo y sin fechar, el texto debió escribirse hacia 1691 para conocimiento del Real Consejo de Aragón, y refería con claridad meridiana (también, probablemente, con exageración en las dos cifras) la dramática situación que conocían los ingresos del maestrazgo de Montesa a fines del siglo XVII.

En otros lugares he descrito y valorado la economía de la orden de Montesa en el momento de su incorporación a la Corona, que tuvo lugar en $1592^{3}$. Pretendo aquí dar cuenta de su evolución durante la centuria siguiente, convencido del interés tanto de algunos de los datos que es posible aportar desde fuentes originales, como de las reacciones a que dio lugar, tanto en la propia Orden como en los órganos de la administración central implicados en su gobierno, el desplome de sus ingresos ${ }^{4}$.

\section{LAS OPTIMISTAS ESTIMACIONES DE FREY JOAN BORJA (1624) Y SU CONTRASTE CON LA SITUACIÓN REAL: LAS CONSECUENCIAS DE LA EXPULSIÓN DE LOS MORISCOS EN LA RENTA DE MONTESA; EL CRECIMIENTO DEL GASTO EN EL MAESTRAZGO}

En 1624, frey Joan Borja, religioso montesiano, capellán de Su Majestad en la Corte, prior de San Jorge de Alfama y rector del colegio de San Jorge de la orden de Montesa en la ciudad de Valencia, redactó a instancias del Consejo de Aragón un completo informe sobre la orden militar valenciana. Era a la vez resumen histórico,

2. Biblioteca Nacional (BN), Manuscritos, $n^{\circ} 2731$, exp. 22, f. 36 .

3. ANDRÉS ROBRES, Fernando, «La economía de la Orden de Montesa cuando la incorporación: patrimonio, renta, gasto, balances (1592-1602), Estudis, Revista de Historia Moderna, 25 (1999), Universidad de Valencia, pp. 55-87; «Política y economía en el Consejo de Aragón: entre la euforia y la ruina (La obra del último maestre y la situación económica de la Orden de Montesa a finales del siglo XVI)», en As Ordens Militares e de Cavalaria na Construção do Mundo Ocidental - Actas do IV Encontro sobre Ordens Militares, Palmela (Portugal), 30 janeiro a 2 fevereiro de 2002, Lisboa, Edições Colibri / Câmara Municipal de Palmela, 2005, pp. 295-315. A esos trabajos, de los que éste es de algún modo complementario -y viceversa-, remito para cualquier aclaración sobre las características de los bienes, rentas y gastos de Montesa.

4. Para el siglo XVIII, la situación económica de Montesa es relativamente mejor conocida. Puede verse SÁNCHEZ DURÁ, María Dolores, Racionalización versus privilegio: la orden de Montesa durante los siglos XVIII y XIX, Tesis de doctorado inédita, Valencia, 1993 (una breve sintesis en «La orden militar de Montesa. Racionalización y privilegio en la España de los siglos XVIII y XIX», Historia social, 19 [1994], UNED, Valencia, pp. 3-29). Una foto fija de las rentas del maestrazgo a caballo entre aquellas mismas centurias puede encontrarse también en AGUADO HIGNÓN, Ana Maria, «Rendes i patrimoni senyorial de l'Orde de Montesa davant la desamortització de Godoyy, en Actes de les Primeres Jornades sobre els Ordes Religioso-Militars als Pä̈sos Catalans (segles XII-XIX), Tarragona, Diputació, 1994, pp. 597-602. 
catálogo de dignidades y empleos, descripción del patrimonio y tasación de rentas y cargos, vertiente que más interesa a este trabajo ${ }^{5}$.

De dar por buena la valoración del eclesiástico, la renta bruta del maestrazgo de Montesa habría seguido progresando en las primeras décadas del seiscientos respecto de la que se registraba a comienzos del siglo. Así se plasma en la tabla $1^{6}$, en concreto a partir de la comparación de los datos de Borja, que elevaba el ingreso hasta las 15.750 libras anuales ${ }^{7}$, con una estimación fechada en 1602 que los tasaba en $13.429^{8}$.

Es verdad, seguramente, que frey Joan pudo pecar de optimista, lo que no dejaría de tener su lógica. Debe considerarse -argumento primero- que, miembro de la Orden y que de ella vivía, bien podría haber tratado de magnificar sus excelencias. Ocurre además -segundo- que ofreció tan solo una estimación bruta, carente de cualquier detalle, algo que resulta extraño en una obra en la que suele destacar, por el contrario, y para la mayor parte de los conceptos, una más precisa descripción?.

Indicios de que comenzaban a llegar tiempos difíciles se manifestaban ya, en tercer lugar, en los arrendamientos de los derechos señoriales de algunas de las trece

5. Breve resolución de todas las cosas generales y particulares de la Orden y Cavallería de Montesa (1624); manuscrito de frey Joan Boria, religioso montesiano; edición y estudio preliminar de Fernando Andrés Robres y Josep Cerdà i Ballester, València, Edicions Alfons el Magnànim, 2004; se conserva el original en el Archivo Histórico Nacional (AHN), Órdenes Militares (OOMM), libro 1364 C; aporta la edición abundante información sobre texto y autor, y mapas sobre el señorío de Montesa en la época; en adelante, Breve resolución...

6. Sin perjuicio de lo comentado en la nota 3, baste aquí recordar que los más importantes conceptos generadores de ingreso de los que la tabla da cuenta, los procedentes de los bailíos (así eran conocidas -por los bailes que las gestionaban - las diferentes circunscripciones en que se hallaba dividida la mesa maestral para la explotación de sus rentas y a otros efectos), obedecían al arrendamiento o a la administración directa en ellos de los derechos señoriales de que la Orden era acreedora (salvo excepciones, puesto que ciertos derechos podían ser explotados por separado).

7. Estimación en ducados (15.000: Breve resolución, cap. 22, p. 20) que convertimos en libras a razón de 1 ducado $=21$ sueldos valencianos; véase al respecto, por ejemplo, VAZQUEZ DE PRADA, Valentín (dir.), Historia Económica y social de España, vol. III (Los siglos XVI y XVII), Madrid, Confederación Española de Cajas de Ahorros, 1978, p. 661. Hemos encontrado en ocasiones en la documentación (por ejemplo en el libro de Borja) cambios distintos ( 22 sueldos por ducado), que no afectarían -más bien al contrario- a la argumentación general que aquí se sostiene. Véase la nota 49.

8. BN, Manuscritos, $\mathrm{n}^{\circ} 2688$, exp. 20, ff. 48 y ss., expediente comentado en «La economía de la Orden de Montesa...». De otra parte, la tabla 1 recoge, como todas, el conjunto de las estimaciones de que disponemos para la variable - o variables- de referencia y el conjunto del siglo XVII; oportunamente se proporcionan las preceptivas referencias.

9. Si bien es cierto que apeló Borja a fuentes supuestamente contrastables. Decía: «La renta que se saca de las sobredichas villas y lugares de la Mensa será passados de quinse mil ducados, con los frutos, sensos y luísmos, fuera de las penas y calonias que se sacan de las dichas villas y lugares, que es cantidad considerable. Todo lo qual se sabe por los libros de la recepta de la mensa maestral de Montesa, como por orden de Su Magestad, pocos meses ha, se le ha hecho relación' (Breve resolución, cap. 22, p. 20). No hemos encontrado por el momento en los fondos consultados dicha relación, pero sí conocemos la fuente, que de hecho utilizamos -aunque de manera indirecta-como se comprobará (véase nota 15); 'recepta' (o 'receta'): llaman los contadores a aquella relación de partidas que se pasan de una contaduria a otra para que aquella se pueda tomar la cuenta el asentista o arrendador (Diccionario de Autoridades, 1737). 


\section{TABLA 1. MAESTRAZGO DE MONTESA. INGRESOS. ESTIMACIONES, 1602-1693. DATOS EN LIBRAS VALENCIANAS}

\begin{tabular}{|c|c|c|c|c|c|c|c|}
\hline & $\begin{array}{l}\text { Estim. } \\
1602\end{array}$ & $\begin{array}{c}\text { Media ingr. } \\
\text { efectivos } \\
1601-10 \\
\end{array}$ & \begin{tabular}{c|} 
Media ingr. \\
efectivos \\
$1611-20$ \\
\end{tabular} & $\begin{array}{c}\text { Borja } \\
1624\end{array}$ & $\begin{array}{l}\text { Beltrán } \\
1632-33\end{array}$ & $\begin{array}{c}\text { Samper } \\
1693\end{array}$ & $\begin{array}{c}\text { Estim. } \\
1693\end{array}$ \\
\hline $\begin{array}{l}\text { BAILÍO DE } \\
\text { CERVERA }\end{array}$ & 6642 & 7149 & 4954 & - & 5475 & - & 3052 \\
\hline $\begin{array}{l}\text { BAILÍO DE } \\
\text { MONCADA }\end{array}$ & 1863 & 1863 & 1741 & - & 1525 & - & 1356 \\
\hline $\begin{array}{l}\text { BAILÍO DE } \\
\text { SUECA }\end{array}$ & 3050 & 2841 & 2703 & - & 3145 & - & 1881 \\
\hline $\begin{array}{l}\text { BAILÍO DE } \\
\text { MONTESA }\end{array}$ & 542 & 560 & 566 & - & 555 & - & 429 \\
\hline Morabatí & - & 182 & 182 & - & 175 & - & \\
\hline Penas y calonias & 50 & $?$ & $?$ & - & 300 & - & 16 \\
\hline $\begin{array}{l}\text { SUBTOTAL } \\
\text { BALLÍOS }\end{array}$ & 12147 & 12413 & 9964 & - & 11175 & - & 6734 \\
\hline $\begin{array}{l}\text { «Responsiones» de } \\
\text { encomiendas }\end{array}$ & 590 & 695 & 695 & 335 & 495 & - & 575 \\
\hline $\begin{array}{l}\text { «esponsiones» de } \\
\text { villas }\end{array}$ & 674 & 520 & 520 & - & 604 & - & 654 \\
\hline $\begin{array}{l}\text { Herbajes y molinos } \\
\text { varios }\end{array}$ & - & - & - & - & 117 & - & \\
\hline Otros ingresos & 18 & 5 & 5 & - & 18 & - & 250 \\
\hline $\begin{array}{l}\text { SUBTOTAL } \\
\text { OTROS } \\
\text { INGRESOS } \\
\end{array}$ & 1282 & 1220 & 1220 & 335 & 1234 & - & 1479 \\
\hline TOTAL & 13429 & 13633 & 11184 & 15750 & 12409 & 8400 & 8213 \\
\hline
\end{tabular}

encomiendas de la propia Orden, y ello según la información proporcionada por el mismo autor. La renta de las encomiendas, que en su conjunto se aproximó a las 17.000 libras anuales en las postrimerías del siglo XVI -la tabla 2 reproduce, junto a la de Borja, una estimación tal vez fiable de $1593^{10}-$, y que habría incluso alcanzado un nivel bastante superior si diéramos crédito -no lo hacemos- a una valoración que circuló en el entorno del Consejo de Órdenes en $1616^{11}$, habría caído, como vemos, hasta las

10. AHN, OOMM, libro 582 C, ff. 167-174, Consulta del Consejo de Aragón de 8 de agosto de 1593.

11. De nada menos que 23.000 ducados de plata: $B N, m s . n^{\circ} 7423$, cit. por DomínGUeZ ORTIZ, Antonio, $L a$ sociedad española en el siglo XVII. I. El estamento nobiliario, Granada, Universidad de Granada - CSIC, $1992^{2}$, p. 200. Se trata de una cantidad inasumible, tanto desde nuestros propios datos como desde los 


\section{TABLA 2. ENCOMIENDAS DE LA ORDEN DE MONTESA. INGRESOS. ESTIMACIONES, 1593-1707. DATOS EN LIBRAS VALENCIANAS}

\begin{tabular}{|l|c|c|c|c|}
\hline & $\begin{array}{c}\text { Consulta agosto } \\
\text { de } \mathbf{1 5 9 3}\end{array}$ & $\begin{array}{c}\text { Borja } \\
\mathbf{1 6 2 4}\end{array}$ & $\begin{array}{c}\text { Beltrán } \\
\mathbf{1 6 3 2 - 3 3}\end{array}$ & $\begin{array}{c}\text { Sala } \\
\mathbf{1 7 0 7}\end{array}$ \\
\hline Benicarló - Vinaròs & 1000 & 1080 & 1080 & 1080 \\
\hline Alcalà & 1500 & 1800 & 1800 & 1800 \\
\hline Mayor (Les Coves) & 2000 & 2200 & 2200 & 2300 \\
\hline Culla (Atzeneta) & 1500 & 1900 & 1900 & 1500 \\
\hline Benasal & 1200 & 1100 & 1100 & 1100 \\
\hline Ares & 650 & 750 & 750 & 750 \\
\hline Vilafamés & 1000 & 900 & 900 & 900 \\
\hline Onda & 650 & 1000 & 1000 & 900 \\
\hline Burriana & 700 & 600 & 600 & 600 \\
\hline Ademuz - Castielfabib & 1000 & 800 & 800 & 800 \\
\hline Silla & 1700 & 2000 & 2000 & 2000 \\
\hline Montroy & 650 & 200 & 200 & 200 \\
\hline Perputxent & 3200 & 1800 & 1800 & 1300 \\
\hline \multicolumn{5}{|l|}{} \\
\hline TOTAL & $\mathbf{1 6 7 5 0}$ & $\mathbf{1 6 1 3 0}$ & $\mathbf{1 6 1 3 0}$ & $\mathbf{1 5 2 3 0}$ \\
\hline
\end{tabular}

Nota: no incluyen las estimaciones los ingresos por «penas y calonias», que debían tener cierta importancia para aquellos casos en que la Orden (y por ende los comendadores) tenía la plena jurisdicción. Por ejemplo, Beltrán estimó que las de la encomienda mayor valdrían, anualmente, unas 500 libras.

16.130 libras en 1624. Y eso que las cifras aportadas por el prior eran todavía altas en muchos casos: los arriendos de las encomiendas de Benicarló-Vinaròs, Alcalà, mayor (Les Coves), Culla, Ares, Onda y Silla se situaban todavía para entonces en cotas superiores a las que habían alcanzado a finales del quinientos y primeros años de la centuria siguiente. Pero esos comportamientos no podían esconder caídas menores en otras varias (Benasal, Vilafamés, Burriana, Ademuz), ni mucho menos podían compensar el auténtico descalabro que el ingreso había experimentado en las encomiendas directamente afectadas por la expulsión de los moriscos, Montroy (de 650 a 200 libras) y Perputxent (de 3.200 a 1.800 libras), y ello a pesar de que los datos de ambas deben considerarse sobrevalorados ${ }^{12}$. El extrañamiento morisco podría pues justificar, por sí sólo, la caída de la renta de las encomiendas de Montesa a la altura de 1624, que

de otros autores, como Casey, que ya habla de sólo 15.000 libras para finales del siglo XVI (CASEY, James, El reino de Valencia en el siglo XVII, Madrid, Siglo XXI, p. 125). Son estos los problemas de las estimaciones generales, en ocasiones no ya groseramente redondeadas, sino posiblemente tendenciosas. Véase también al respecto, más adelante, nota 34.

12. Para la primera véase SOLER, Abel, y YAGo, Ramón, Montroy. Geografia, Historia, Patrimonio, Catadau, Ayuntamiento de Montroy, 2004, en cuyas pp. 69-74 se documenta la gravedad de la crisis y las dificultades de la repoblación en el lugar desde fuentes originales; para la de Perputxent, Breve Resolución, cap. 73 , notas. 
confirma la casi inmediata estimación (1632-33) de otro religioso montesiano, frey Miguel Beltrán ${ }^{13}$, y que parece había emprendido una tendencia decreciente -a lo sumo de estabilidad- en términos generales, en lógica concordancia con una coyuntura de precios estancados o a la baja.

El carácter cristiano-viejo del poblamiento de los bailíos del maestrazgo, abrumador $^{14}$, podría quizá justificar los buenos datos que para los ingresos maestrales registraba Borja. Pero el argumento es insuficiente para sostener una suposición que no cuenta con ningún otro apoyo. Juega en su contra la evolución de los precios, la misma, por supuesto, en encomiendas y maestrazgo. Y juega en su contra, sobre todo, y lo hace con contundencia, la cruda realidad que nos muestran fuentes alternativas.

Podemos casi asegurar, en efecto, que la estimación de Borja no se correspondía con la verdad en lo referido a las entradas de la mesa maestral de la Orden. La tabla 1 recoge, como vemos, anteriores a la de Borja y posteriores a la de 1602 , otras dos valoraciones de ingresos para el primer cuarto del siglo; las llamamos medias de ingresos efectivos, y disponemos de una para cada una de las décadas 1601-10 y 1611-20. Han sido obtenidas de la elaboración de datos contenidos en un valioso trabajo de Hélène Tropé, inédito, que bucé para conseguirlos en los libros de contabilidad de la propia Orden que se conservan en el Archivo del Reino de Valencia ${ }^{15}$.

Su lectura no parece ofrecer lugar a dudas. Desde la referencia de la estimación de 1602 , que resulta ratificada con sólo pequeñas y compensadas desviaciones por los ingresos reales registrados en 1601-10, la renta del maestrazgo de Montesa habría comenzado a caer a renglón seguido, extremo que refleja la estimación de ingresos reales de 1611-20 (véase para todo ello la tabla 1), y al que alude de forma explícita y reiterada la propia doctora Tropé en su trabajo ${ }^{16}$.

13. Beltrán y Peris, frey Miguel, Libro de las Visitas, Capitulos Generales, Bullas Apostólicas y otras cosas tocantes a la Orden de Montesa, manuscrito, 1633 (BN, ms. nº 845, ff. $6 \mathrm{v}-11$ ); en adelante, BELTRÁN, Libro visitas 1633. Las estimaciones de Beltrán han sido llevadas sistemáticamente a las tablas, lo que supone, en los casos en que estas reproducen las ya presentadas en trabajos complementarios (véase nota 3), enriquecerlas, pues para entonces no habíamos explotado este registro. El libro de Beltrán no resulta demasiado creíble para ciertas estimaciones, como es el caso, que entendemos debió copiar del de Borja (su valoración resulta idéntica encomienda a encomienda), como probablemente hizo con tantas otras cosas y muchas veces (por ejemplo, en la descripción del patrimonio); aunque, con carácter excepcional, sí parece más fiable y preciso en otras valoraciones, que comentaremos pronto.

14. Véase «La economia de la Orden de Montesa...», p. 64.

15. Tropé, Hélène, La Orden de Montesa: estudio de las rentas de la bailia de Cervera: 1587-1623, París, 1983, 3 vols., memoria de licenciatura mecanografiada, Université de la Sorbonne Nouvelle Paris III, U.E.R. d'Études lbériques. Comento con algún detalle ese trabajo en «La economía de la Orden de Montesa...», donde también aludo a los criterios seguidos para la elaboración de las estimaciones que presento en mis tablas a partir de los datos, desnudos en su mayor parte, que proporciona la profesora Tropé. Baste aquí con saber que, en su mayor parte -y desde luego en lo que se refiere a las rentas de los bailios-, las valoraciones reflejan datos medios de los ingresos efectivos habidos en la mesa maestral de Montesa en los ejercicios contables de referencia. Los libros son, por supuesto, los antes aludidos «libros de recepta》 (véase nota 9 ).

16. TROPÉ, H., op. cit., vol. I, pp. 143 y 171-199. 
Ahondando un poco en las cifras sorprende un tanto el carácter irregular de la caída, imperceptible en el bailío de Montesa, discreta en los de Sueca y Moncada -ambos en comarcas feraces-, pero intensa (de más del 30\%), en el corazón y principal dominio de la mesa maestral de Montesa, el bailío de Cervera, centro del llamado maestrazgo viejo. Hélène Tropè, que dedicó lo mejor de su investigación a ese territorio en concreto, explica el descenso, en parte, aludiendo a la evolución general de los precios, pero lo pone sobre todo en relación con el proceso de despoblación que, como consecuencia de la expulsión de los moriscos, habría experimentado la comarca. Desde luego que no habrían sido moriscos quienes habrían marchado del más septentrional de los bailíos del maestrazgo de Montesa -pues no los había-, sino cristiano-viejos que habrían acudido, precisamente, a ocupar las tierras abandonadas más al sur y a la fuerza por los moriscos expulsos. Esa tesis, a la que no falta apoyo documental ${ }^{17}$, vendría por otra parte a insistir en la necesidad de revisar las tesis más extendidas acerca de las características de la repoblación que siguió a la expulsión, algo que hoy admiten los autores tanto del valioso trabajo donde en origen se formularon ${ }^{18}$ como de la más reciente síntesis sobre la historia rural del País Valenciano en la edad moderna ${ }^{19}$.

En definitiva, Borja no se ajustó al parecer a la realidad en su estimación. La renta del maestrazgo de Montesa no había de ser excepción en una evolución general ya bien documentada y, como en la inmensa mayoría de los casos, atravesaba dificultades. Respecto de la referencia anterior -1602- no sólo no habría crecido en las más de dos mil libras que proponía el religioso, sino que habría menguado en una cantidad similar. Desviación absoluta, pues, de más de cuatro mil libras, y por tanto muy importante. Cabe pensar en la posibilidad de que el clérigo amañara su estimación intencionadamente. Pero es también válido suponer que no necesitara hacerlo: es probable que una valoración teórica de la renta del maestrazgo en 1624 permitiera llegar a aquellas casi 16.000 libras; tan probable como seguro es afirmar que el ingreso efectivo se situaba muy por debajo, y había descendido, y bastante, respecto de los niveles que eran normales una veintena de años atrás.

Lo asevera al fin la estimación de frey Miguel Beltrán de sólo unos pocos años después (1632-33), que sí la hizo diferente de la de Borja y más detallada para este concepto. Con matices, puesto que sus cifras mejoran algo las medias de los ingre-

17. Y no sólo el cuantitativo ya visto (la fractura del ingreso), sino cualitativo, como es el caso de una elocuente carta del «bayle» de Montesa en el maestrazgo viejo, que en 1612 y al justificar ante la Junta Patrimonial del Reino - a la sazón encargada de la gestión económica del maestrazgo- lo menguado del ingreso, confesaba lo siguiente: «Porque desde la expulsión de los moriscos, en dicho maestrasgo hay muy grande quiebra y muchas eredades sin cultivar, por haverse ido muchas personas a poblar lugares de moros, y assí mesmo los precios de los frutos no son como los annos pasados»). Reproduzco la cita desde TROPÉ, H., op. cit, vol. I, pp. 182-183.

18. CisCar PAllarés, Eugenio, Tierra y señorio en el País Valenciano (1570-1620), València, Del Cenia al Segura, 1977, passim.

19. ARdT LUCAS, Manuel, Els homes $i$ la terra del País Valencià (segles XVI-XVIII), Barcelona, Curial, 1993, vol. I, pp. 197-214. 
sos reales de 1611-21 (véanse en particular los ingresos de los bailíos de Cervera y Sueca), aun cuando al cabo confirman aquella valoración en lo fundamental ${ }^{20}$.

Frey Joan Borja podía tener motivos, hemos intentado entenderlo, para tratar de dar realce al ingreso, y se habría escudado para ello, acaso, en la renta posible. ¿Pudo también ofrecer una información interesada sobre los gastos del maestrazgo? Lo creo menos probable. En la misma lógica de su doble intención de ensalzar la Orden y agradar al monarca, parece que no tendría demasiado sentido manipular las cifras de los dispendios, y en ninguna dirección. Pensando en que los gastos se destinaban en buena parte al pago de los salarios y raciones de sus hermanos de hábito y al mantenimiento del patrimonio y de la dignidad de la institución, parece descartable que Borja apuntara por defecto; mas puesto que a nadie halaga una exageración de sus obligaciones (y menos a Su Majestad), el exceso parece también improbable.

Aún con ello ocurre que el dato más sobresaliente de entre todos los aportados por Borja, por haber sufrido una desviación mayor respecto de estimaciones anteriores, es el correspondiente al gasto. Un gasto que se disparaba y que, en consecuencia, destrozaba los proyectos de austeridad una y otra vez invocados desde el Consejo de Aragón en las consultas redactadas con motivo de la incorporación. Habría crecido, nada menos -véase tabla 3-, de 8.933 libras anuales (dato otra vez de 1602) a 13.086; o, lo que es lo mismo, un 46,5\%, afectando a todas y cada una de sus partidas principales $y$, por cierto, sin que además cupiera culpar de ello lo más mínimo al último maestre ${ }^{2 !}$. Por si fuera poco, Beltrán no solo ratifica esos gastos, sino que los incrementa incluso hasta alcanzar un total de casi 14.500 libras, con aporte de datos novedosos para ciertas partidas, aunque no para todas.

El aumento del gasto correspondiente al convento de la Orden -sito para entonces y hasta el terremoto de 1748 en la villa de Montesa-, y al colegio de San Jorge -en la ciudad de Valencia-, que se destinaba sobre todo a alimentación y vestuario, estaba en parte justificado. Sucesivas disposiciones de los monarcas en su calidad de «administradores perpetuos» habían ido autorizando el aumento del número de conventuales y colegiales, de modo que hacia 1624 eran ya veintiséis frente a los catorce que estipulaban las «difiniciones» del instituto ${ }^{22}$, suficien-

20. La cantidad final se ve acrecentada, también, por cuanto cuantifica los ingresos en concepto de penas y calonias, lo que no hicieron anteriores estimaciones.

21. Véanse al respecto «La economía de la Orden de Montesa...» y, sobre todo, «Política y economía en el Consejo de Aragón....».

22. Por resumir, da cuenta de las progresivas ampliaciones una consulta del Consejo de Aragón sin fechar (1604?) en AHN, OOMM, libro $582 \mathrm{C}$, pp. 74-93. El incremento de conventuales estuvo en relación con las necesidades a que dio lugar la bula que la propia Orden bautizó como «Áurea», impetrada en 1604 y que supuso para Montesa la recuperación de los derechos para la provisión de bastantes rectorías en villas y lugares de su territorio: véase al respecto la Parte Segunda de la Breve resolución, en particular el cap. 9. Crecieron con ello los gastos conventuales -gastos en educación de clérigos montesianos preparados para cubrirlas-. Pero creció también, y mucho más, la renta en manos de los freiles clérigos de Montesa que ocupaban empleos (particularmente curatos) con dotación propia: hasta el punto que pasó de las poco más de 1.500 libras que encontrábamos en 1592 (véase «La economía de la Orden de Montesa...») a más 12.000 libras en 1624 (sin 
tes para comprender que hicieran falta 5.250 libras donde antes bastaban unas $3.500^{23}$.

Y también se había visto desbordado - multiplicado casi por dos desde 1602 y por tres desde 1593-, hasta alcanzar las 2.600 libras anuales con Borja y 3.300 con Beltrán, el apartado del gasto dedicado a salarios, una vez perfilada la nueva planta administrativa de la Montesa incorporada y considerados empleos antes olvidados, como los «bayles» de las circunscripciones de la mesa ${ }^{24}$. Más o menos la mitad de esa cantidad se pagaba por empleos ejercidos en el territorio de la Orden, mientras iban creciendo con pasos de gigante los que debían hacerse efectivos en la Corte (ya cuando Borja) y en Valencia (véanse los datos de Beltrán). Por cierto: en absoluto se había llevado a efecto, tampoco, la también una y otra vez expresada intención de recortar el número y los niveles de los salarios destinados a abogados y procuradores ${ }^{25}$.

Tan sólo con esas alteraciones, el gasto que hemos venido a considerar ordinario se habría incrementado en nada menos que 2.500 libras lineales anuales en las dos primeras décadas de la centuria, pasando de 5.500 libras en 1602 a 8.000 en 1624 , y en casi otras 1.000 en 1632 , como advierte la tabla $4^{26}$.

Y algo parecido había ocurrido con el extraordinario, consistente en pensiones dinerarias ${ }^{27}$. Cabe destacar además la intensa transformación que habrían experimen-

considerar, eso sí, ciertos cargos a que obligaban las rectorías), elevando quizá el conjunto de la renta bruta generada en torno a la Orden (y por mucho que estas rentas estrictamente eclesiásticas funcionaran independientemente de la administración de la institución) hasta más allá de las 40.000 libras hacia el primer cuarto del siglo XVII, frente a las poco más de 30.000 de cuando la incorporación.

23. De cualquier forma, si recordamos que el virrey consideraba suficientes 1.500 libras anuales en 1592 (AHN, OOMM, libro 582 C, ff. 20-21), podremos deducir que tampoco se había llevado a la práctica ninguna medida de austeridad por individuo de las aconsejadas por el Consejo de Aragón cuando la incorporación. Podemos así señalar, como ejemplo, que el prior recibía en 1624 hasta 100 libras anuales en concepto de vestuario (Breve resolución, Primera Parte, cap. 24), contra las 30 recomendadas en una consulta del Consejo de Aragón específica sobre el convento fechada en agosto de 1593 (AHN, OOMM, libro $582 \mathrm{C}$, ff. 167-174).

24. Algunos de ellos, enajenados a menudo a particulares no miembros de la Orden y por una o varias vidas, representaban gastos nada despreciables, como las 450 libras anuales que correspondían al baile del «maestrazgo viejo»; que eran en realidad 600, aunque el salario llevaba implícita la obligación de pagar la ayuda para vestuario del subcomendador del convento de Montesa, 150 libras, en otra de aquellas extrañas combinaciones que caracterizaban las finanzas de la Orden y que he corregido en la elaboración de la tabla 3 (véase Breve Resolución, Primera Parte, cap. 79).

25. Véase «Política y economía en el Consejo de Aragón...».

26. Los restantes gastos ordinarios habrían permanecido estables, y seguían siendo menudos. Se habría logrado incluso evitar algunos pagos en especie, como los antes satisfechos a algunas rectorías del territorio, una vez que su provisión recaía ya en 1624 en la propia Orden. Véase nota 22.

27. La documentación no establece, por supuesto, tal diferenciación, incluyendo el conjunto del gasto en un mismo saco. Pero considero más correcto entender las pensiones como excedente comprometido y no como gasto ordinario (véase «La economía de la Orden de Montesa...»). 
TABLA 3. EL GASTO DEL MAESTRAZGO DE MONTESA. ESTIMACIONES, 1602 - 1693. DATOS EN LIBRAS VALENCIANAS

\begin{tabular}{|c|c|c|c|c|}
\hline & $\begin{array}{c}\text { Estim. } \\
1602\end{array}$ & $\begin{array}{c}\text { Borja } \\
1624\end{array}$ & $\begin{array}{l}\text { Beltrán } \\
1632-33 \\
\end{array}$ & $\begin{array}{l}\text { Estim. } \\
1693\end{array}$ \\
\hline Alimentos convento & 1891 & 2907 & 2906 & 1536 \\
\hline Vestuarios convento (prior, sosclavero, religiosos) & 425 & 490 & 490 & 700 \\
\hline Vestuario soscomendador & inc. & 150 & 150 & 150 \\
\hline Cera convento & inc. & 100 & 100 & 100 \\
\hline Limosnas convento & inc. & 55 & 55 & 137 \\
\hline Trigo convento & 550 & 760 & 760 & 841 \\
\hline Vino convento & 460 & 532 & 532 & 545 \\
\hline Aceite convento & 134 & 130 & 130 & 237 \\
\hline Cebada animales convento & inc. & 33 & 99 & 137 \\
\hline Algarrobas animales convento & 36 & 36 & inc. & 36 \\
\hline Paja animales convento & 30 & 30 & inc. & 30 \\
\hline Misas por S. M. en convento & 10 & 10 & 10 & 10 \\
\hline Beneficios simples convento (tres) & 15 & 15 & 15 & 15 \\
\hline Para gastos extraordinarios & - & - & - & 350 \\
\hline Medicinas, médico y cirujano convento & - & - & - & 180 \\
\hline Huéspedes & - & - & - & 20 \\
\hline Salarios criados & - & - & - & 24 \\
\hline Salarios cocina (cocinero, mozo) & - & - & - & 37 \\
\hline Salario organista & - & - & - & 30 \\
\hline Salario acemilero & - & - & - & 27 \\
\hline Salario lavandera & - & - & - & 46 \\
\hline Salarios comprador y abogado en Xàtiva & - & - & - & 10 \\
\hline $\begin{array}{l}\text { Salarios médico y lavandera en el colegio } \\
\text { de San Jorge (Valencia) }\end{array}$ & - & - & - & 50 \\
\hline Intereses, trueques y portes dinero & - & - & - & 90 \\
\hline Sin especificar & - & - & - & 21 \\
\hline SUBTOTAL CONVENTO Y COLEGIO & 3551 & 5248 & 5247 & 5359 \\
\hline Capellanes en Madrid & 338 & 353 & 353 & - \\
\hline Procurador en la Corte & 211 & 440 & 220 & 529 \\
\hline Secretario de Montesa en el Consejo Aragón & - & 300 & 300 & 223 \\
\hline Portero Consejo Aragón & 39 & 40 & 40 & 40 \\
\hline Asesor General de la Orden & - & - & 200 & 265 \\
\hline Agente de Montesa en Roma & & & 50 & \\
\hline SUBTOTAL SALARIOS EN MADRID & 588 & 1133 & 1163 & 1057 \\
\hline $\begin{array}{l}\text { Lugarteniente General de S. M. de Montesa en } \\
\text { Valencia }\end{array}$ & - & Palacio & 300 & 385 \\
\hline Escribano & - & - & & 30 \\
\hline Tesorero & - & - & & - \\
\hline Asesores del Lugarteniente General en Valencia & - & - & & - \\
\hline
\end{tabular}




\begin{tabular}{|c|c|c|c|c|}
\hline & $\begin{array}{c}\text { Estim. } \\
1602\end{array}$ & $\begin{array}{c}\text { Borja } \\
1624\end{array}$ & $\begin{array}{l}\text { Beltrán } \\
1632-33 \\
\end{array}$ & $\begin{array}{c}\text { Estim. } \\
1693\end{array}$ \\
\hline $\begin{array}{l}\text { Alguacil del tribunal del Lugarteniente General } \\
\text { en Valencia }\end{array}$ & - & Penas & 50 & - \\
\hline Otros alguaciles del tribunal & - & Dietas & & - \\
\hline $\begin{array}{l}\text { Portero del tribunal del Lugarteniente General } \\
\text { en Valencia }\end{array}$ & - & 60 & 40 & 60 \\
\hline Abogado patrimonial y fiscal & 12 & 12 & 12 & 32 \\
\hline Abogado ordinario & 12 & - & 12 & 12 \\
\hline Síndico y procurador fiscal de Montesa en Valencia & 35 & 35 & 40 & 70 \\
\hline Portero del la Junta Patrimonial del Reino de Valencia & - & 19 & & - \\
\hline Receptor de la Mesa Maestral & - & - & 200 & 225 \\
\hline Alcaide del palacio y cárcel del Temple & - & - & & 30 \\
\hline Procurador eneral de Montesa en Valencia & - & $-\ldots$ & & 100 \\
\hline Secretario del Lugarteniente General en Valencia & - & - & & 25 \\
\hline Maestre Racional del Reino de Valencia & - & - & & 300 \\
\hline SUBTOTAL SALARIOS EN VALENCIA & 59 & 126 & 654 & 1269 \\
\hline Lugarteniente de Montesa en el Maestrazgo Viejo & 300 & 300 & 300 & 300 \\
\hline Asesor del Lugarteniente del Maestrazgo Viejo & 100 & 100 & 100 & 100 \\
\hline Abogado patrimonial y fiscal en el Maestrazgo Viejo & 12 & 12 & 12 & 12 \\
\hline Procurador patrimonial y fiscal en el Maestrazgo Viejo & 12 & 12 & 12 & 12 \\
\hline $\begin{array}{l}\text { Colector de las penas y calonias en el Maestrazgo } \\
\text { Viejo }\end{array}$ & - & - & & - \\
\hline $\begin{array}{l}\text { Baile del Mtzgo Viejo (más } 150 \text { que da al soscom. de } \\
\text { Montesa) }\end{array}$ & - & 450 & 450 & - \\
\hline Lugarteniente (o gobernador) en Sueca & 100 & 100 & 100 & 100 \\
\hline Baile de Sueca & - & 230 & 230 & - \\
\hline $\begin{array}{l}\text { Lugarteniente (o gobernador) en Montesa } \\
\text { (subclavero) }\end{array}$ & - & Penas & Penas & - \\
\hline \multicolumn{5}{|l|}{ Baile de Montesa } \\
\hline Asesor del lugarteniente en Montesa & 10 & 10 & 10 & - \\
\hline Lugarteniente (o gobernador) en Moncada & 100 & 100 & 100 & 100 \\
\hline Baile de Moncada & 20 & 20 & 20 & 20 \\
\hline Gastos soldados en la Torre de Alfama & 141 & - & 141 & - \\
\hline Cargo sin identificar & 40 & - & & - \\
\hline SUBTOTAL SALARIOS EN EL TERRITORIO & 835 & 1334 & 1475 & 644 \\
\hline SUBTOTAL CONJUNTO SALARIOS & 1482 & 2593 & 3292 & 2970 \\
\hline Pensión al prior de Alfama & 17 & 17 & 17 & 17 \\
\hline 42 cahíces trigo a rectores & - & - & & - \\
\hline Beneficio en Canet & 9 & 8 & 9 & 9 \\
\hline Pensión al prior de Cervera & 15 & - & 15 & 15 \\
\hline SUBTOTAL OTROS GASTOS ECLESIÁSTICOS & 41 & 25 & 41 & 41 \\
\hline
\end{tabular}




\begin{tabular}{|l|c|c|c|c|}
\hline & $\begin{array}{c}\text { Estim. } \\
\mathbf{1 6 0 2}\end{array}$ & $\begin{array}{c}\text { Borja } \\
\mathbf{1 6 2 4}\end{array}$ & $\begin{array}{c}\text { Beltrán } \\
\mathbf{1 6 3 2 - 3 3}\end{array}$ & $\begin{array}{c}\text { Estim. } \\
\mathbf{1 6 9 3}\end{array}$ \\
\hline $\begin{array}{l}\text { Pensiones concedidas por el maestre Galcerán de } \\
\text { Borja }\end{array}$ & 2131 & 300 & 200 & - \\
\hline Compañías [paniaguas], cuatro & 200 & 200 & 200 & 150 \\
\hline $\begin{array}{l}\text { Mercedes (pensiones) concedidas por } \\
\text { los reyes-administradores }\end{array}$ & 1286 & 4720 & 3490 & - \\
\hline Censos a particulares & 27 & - & & 19 \\
\hline Pólvora soldados Torre Alfama & 15 & - & & - \\
\hline Obras & 200 & - & 1500 & 500 \\
\hline Gastos de la fiesta de San Jorge en Madrid & - & - & 220 & 203 \\
\hline Gastos de la fiesta de San Jorge en Valencia & - & - & & 150 \\
\hline Luminarias & - & - & & 300 \\
\hline Gastos subastar arriendos & - & - & & 50 \\
\hline Gastos varios de la administración de justicia & & & 300 & \\
\hline SUBTOTAL VARIOS & 3859 & 5220 & 5910 & 1372 \\
\hline & & & & \\
\hline TOTAL GENERAL & $\mathbf{8 9 3 3}$ & $\mathbf{1 3 0 8 6}$ & $\mathbf{1 4 4 9 0}$ & $\mathbf{9 7 4 2}$ \\
\hline
\end{tabular}

inc. = incluido; $-=$ partida no aparece en esa estimación

tado. En franca disminución las llamadas «pensiones de Garcerán» ${ }^{28}$ al haber fallecido la mayor parte de sus titulares a la altura de 1624 -se pagaban para entonces por ese concepto tan sólo 300 libras anuales frente a las 2.131 de $1602^{29}$, un verdadero aluvión de nuevas «mercedes que las magestades de los reyes Don Phelippe segundo y Don Phelippe tercero y Don Phelippe quarto han hecho como Administradores Perpetuos de la Orden a differentes cavalleros y a otros sobre la mensa maestral de Montesa $\aleph^{30}$ se encargaban de elevar hasta 4.720 libras anuales una carga que en 1602 era de sólo 1.286 libras. El uso (y acaso abuso) del maestrazgo de Montesa como

28. Asignaciones vitalicias que, con cargo a la renta maestral, había exigido el último maestre al monarca como contraprestación en la negociación que habia conducido a la incorporación: véase al respecto ANDRÉS ROBRES, F., «Garcerán de Borja, Felipe II y la tardía incorporación del maestrazgo de la Orden de Montesa a la Corona. Los hechos (1492-1592)», en MArTínez Ruiz, Enrique, y SUÁrez Grimon, Vicente (eds.), Iglesia y Sociedad en el Antiguo Régimen. III Reunión Científica de la Asociación Española de Historia Moderna, Las Palmas de Gran Canaria, Universidad, 1994, pp. 409-420. También, «La economía de la Orden de Montesa...».

29. Correspondían a tres pensiones de 100 libras cada una, que cobraban tres caballeros ancianos. Frey Joan Borja da cuenta en su Breve resolución del conjunto de las «pensiones de Garcerán», de sus titulares, cuantía y fecha de extinción (Primera Parte, cap. 23).

30. Breve resolución, cap. 28. Se trataba de un total de 18 asignaciones, con dotaciones anuales de entre 100 y 600 libras. Destacaban las concedidas a algunas viudas, entre las que se encontraba, por ejemplo, la del vicecanciller de Aragón y primer asesor general de la Orden don Diego Covarrubias (600 libras concedidas en 1609). Entre los caballeros beneficiados encontrábamos al hijo ilegítimo de Galcerán, don Pedro Luis (300 libras concedidas en 1614), y otros dos Borja: Carlos (200 libras) y Baltasar (150 libras). El secretario del antiguo maestre, Luis de Berbegal, recibía también 150 libras anuales. 
TABLA 4. LAS FINANZAS DEL MAESTRAZGO DE MONTESA, 1602-1693. SÍNTESIS DE INGRESOS Y GASTOS. BALANCES.. DATOS EN LIBRAS VALENCIANAS

\begin{tabular}{|c|c|c|c|c|c|c|}
\hline & & $\begin{array}{c}\text { Estim. } \\
1602 \\
\text { (ingresos } \\
\text { y gastos) }\end{array}$ & $\begin{array}{l}\text { Media ingr. } \\
\text { efectivos } \\
\text { 1611-20 / } \\
\text { / gastos } \\
\text { Borja, 1624 }\end{array}$ & $\begin{array}{c}\text { Borja } \\
1624 \\
\text { (ingresos } \\
\text { y gastos) }\end{array}$ & $\begin{array}{c}\text { Beltrán } \\
1632-33 \\
\text { (ingresos } \\
\text { y gastos) }\end{array}$ & $\begin{array}{c}\text { Estim. } \\
1693 \\
\text { (ingresos } \\
\text { y gastos) }\end{array}$ \\
\hline A & TOTAL INGRESOS & 13379 & 11184 & 15750 & 12409 & 8213 \\
\hline a & Salarios Madrid & 588 & 1133 & 1133 & 1163 & 1057 \\
\hline$b$ & Salarios Valencia & 59 & 126 & 126 & 654 & 969 \\
\hline $\mathrm{c}$ & Salarios territorio & 835 & 1334 & 1334 & 1475 & 644 \\
\hline $\mathrm{d}$ & Total salarios $(a+b+c)$ & 1482 & 2593 & 2593 & 3292 & 2670 \\
\hline $\mathrm{e}$ & Gasto del Convento & 3551 & 5248 & 5248 & 5247 & 5359 \\
\hline$f$ & Otros gastos ordinarios $\left({ }^{*}\right)$ & 483 & 225 & 225 & 2261 & 1713 \\
\hline B & $\begin{array}{l}\text { Tot. gastos ordinarios } \\
(d+e+f)\end{array}$ & 5516 & 8066 & 8066 & 10800 & 9742 \\
\hline $\mathrm{g}$ & Pensiones Garcerán & 2131 & 300 & 300 & 200 & 0 \\
\hline $\mathrm{h}$ & Mercedes reyes & 1286 & 4720 & 4720 & 3490 & 0 \\
\hline $\mathrm{C}$ & $\begin{array}{l}\text { Tot.gastos extraordinarios } \\
(\mathrm{g}+\mathrm{h})\end{array}$ & 3417 & 5020 & 5020 & 3690 & 0 \\
\hline $\mathrm{D}$ & TOTAL GASTOS $(\mathrm{B}+\mathrm{C})$ & 8933 & 13086 & 13086 & 14490 & 9742 \\
\hline $\mathrm{E}$ & BALANCE 1 (A-D) & 4446 & -1902 & 2664 & -2081 & -1529 \\
\hline $\mathrm{F}$ & BALANCE 2 (A-B) & 7863 & 3118 & 7684 & 1609 & -1529 \\
\hline
\end{tabular}

* Incluye «Otros gastos eclesiásticos» y «Gastos Varios» de la tabla 3 (excepto «Pensiones Garcerán» y «Mercedes Reyes»).

fuente de concesión de mercedes continuaba así su trayectoria lógica. Después (163233), cuando parece se había puesto freno a nuevas concesiones y comenzaba a recuperarse renta con la muerte de algunos de los beneficiarios (véase la tabla 3), Beltrán recordaba la necesidad de acudir en auxilio de un patrimonio inmueble tal vez muy 
deteriorado, incrementando con crudeza el gasto asignado a obras, que entendemos gasto ordinario.

Con lo expuesto puede sostenerse que la estructura financiera del maestrazgo de Montesa bien podría haber comenzado a experimentar serios problemas ya en el primer tercio del siglo XVII. Sólo los hubiera evitado en caso de ser ciertas las cifras del ingreso que manejaba Borja, pero no en la mucho más razonable opción de considerar más fiables la media de ingresos reales de la década 1611-20 y la estimación que debemos a frey Miguel Beltrán.

Todos los supuestos son contemplados en la tabla 4, donde se realizan cálculos que hay que entender, resulta obvio, como meramente aproximativos, e incluso en ocasiones hasta especulativos. Si atendemos a su Balance 2, que pone en relación ingresos y gastos ordinarios, aún cabria la tranquilidad: desde luego con los datos de ingresos y gastos de Borja, con los que Montesa arrojaría un saldo positivo anual de 7.684 libras, estable respecto de las referencias anteriores no ya sólo de 1602 -que refleja la misma tabla-, sino también de 1592 y $1593^{31}$; también, considerando los ingresos medios reales de 1611-20; e incluso con los datos de Beltrán, aunque con sus cifras el margen se vea muy recortado (hasta solo 1.609 libras anuales) como consecuencia doble del severo descenso en la estimación del ingreso (que comparte el cálculo anterior) y el incremento del gasto ordinario (en concreto, en salarios y en obras).

Además, el Balance 2 no era el balance efectivo, que hay que calcular -es evidente- una vez satisfechos también los gastos extraordinarios. Considerándolos, el relativo sosiego habido al respecto desde la incorporación se quebraba para dar lugar a la aparición, quizá, de los primeros números rojos, encarnados en el déficit de 1.902 libras anuales que resulta de la comparación de la media de ingresos reales en 1611-20 con los gastos que relaciona Borja, o de los 2.081 que arroja el mismo cálculo con las estimaciones de frey Miguel Beltrán de 1632-33.

Posibles dificultades pues. Pero que nada tenían que ver todavía con las que habrían de afrontarse tan sólo unas pocas décadas más tarde.

\section{LAS CUENTAS EN LA SEGUNDA MITAD DEL SIGLO.}

\section{LAS ENCOMIENDAS Y LOS PROBLEMAS CON SUS FUENTES. EL MAESTRAZGO: HUNDIMIENTO DE LA RENTA, RESISTENCIA DEL GASTO, MEDIDAS DE URGENCIA E INICIATIVAS DESESPERADAS}

Las estimaciones que sobre la renta de Montesa disponemos para la segunda mitad de siglo resultan, si tuviéramos que aceptar sin más la información que en bruto nos proporcionan, un tanto desconcertantes.

Las principales sospechas recaen en los resultados obtenidos para las encomiendas, sobre las que disponemos únicamente de un par de valoraciones: una que sólo es

31. Véase «La economía de la Orden de Montesa...», tabla 7, del que la presente no es sino continuación. 
posible datar entre 1652 y $1671^{32}$ y otra fechada en $1707^{33}$. De hacer caso a la primera estaríamos, ni más ni menos, ante un milagro. Evalúa la renta, para el conjunto -no desciende a detallar lo tocante a cada una-, en nada menos que 23.000 ducados de plata, cantidad de todo punto inverosímil desde la anterior referencia, que debemos a Borja en 1624 (y que refrendó o copió Beltrán en 1632-33): 16.130 libras (tabla 2). Por lo demás, la cifra resulta ser sospechosamente idéntica a la de otra estimación de 1616 que ya habíamos comentado y de la que habíamos también desconfiado ${ }^{34}$.

La supuestamente más fiable valoración de 1707, que procede de un muy sintético informe sobre la Orden de Montesa cuyo destinatario era Felipe V y que sí proporciona datos pormenorizados para cada encomienda, resulta por su parte coincidente en lo esencial con los datos de Borja y Beltrán. Apuntaría, en consecuencia -véase tabla 2- hacia una relativa estabilidad de la variable. Algún ligero incremento - «encomienda mayon) - se habría visto más que contrarrestado con otros descensos (Culla, Onda), mientras continuaban su caída las rentas de Perputxent, lo que llevaba al total a niveles inferiores en casi 1.000 libras a los encontrados en 1624 y 1632 . Con todo, continúa pareciéndonos ése un comportamiento sospechoso por demasiado estable, y es por ello que nos inclinamos por pensar que, o bien tampoco debe otorgarse excesiva credibilidad a dicha valoración, o bien -y quizá sea esta la hipótesis más verosímil- los datos de 1707 estarían reflejando ya el momento de retorno en un movimiento pendular que años atrás habría conducido las rentas de los arrendamientos de los derechos dominicales de las encomiendas de Montesa a niveles inferiores. Sostiene esa posibilidad en nuestras fuentes un dato puntual que consideramos indicio significativo: en la Breve resolución, en el capítulo dedicado precisamente a la encomienda de Culla, una anotación posterior y hecha al margen, por supuesto de distinta mano a la del autor del texto original, añadió: «el año de 1672 se arrendó en 1200 libras» ${ }^{35}$; la cifra daría cuenta, de

32. Archivo de la Real Academia de la Historia (RAH), Colección Salazar y Castro (CSC), sign. 9/590, f. $7 \mathrm{v}$; se trata de una estimación anónima y sin fecha, pero indica que era para entonces vicecanciller de Aragón don Cristóbal Crespí de Valldaura, cuyo mandato se desarrolló entre los referidos años: véase ARrIETA AlBERd, Jon, El Consejo Supremo de la Corona de Aragón (1494-1707), Zaragoza, Institución «Fernando el Católico», 1994, p. 199.

33. RAH, CSC, 9/609, fols. 99-101, informe sobre la Orden de Montesa, firmado por don Pasqual de la Sala. Debe referirse a don Pasqual Félix de la Sala, que figura entre los nombres de un listado del libro manuscrito que contiene el texto de Borja (pero escrito de otras manos) bajo el rótulo «Officiales que ha tenido la Secretaría de Montesa desde su institución»: véase Breve Resolución, p. 3 recta; y, sobre todo, la descripción del listado en el «Estudio Preliminar» de la edición del texto a cargo de Fernando Andrés y Josep Cerdà ya comentada.

34. Véase nota 11. Ambas habían circulado en el entorno del Consejo de Órdenes, en el que Montesa no estaba todavia integrada entonces (al respecto, ANDRÉS ROBRES, F., «La singularidad de la hermana pequeña. Algunas consideraciones sobre el gobierno de la orden de Montesa y sus relaciones con la monarquía (siglos XVI-XVIII)», Hispania, 190 [1995], pp. 547-566). La desconfianza en ambas es tal que ninguna de las dos estimaciones se ha incluido siquiera en la tabla 2.

35. cap. 51, p. $59 \mathrm{v}$. 
ser cierta, tanto de la intensidad de la crisis del seiscientos en la zona como de que el proceso de recuperación se habría iniciado ya en el momento del informe de Sala ${ }^{36}$.

Porque, eso sí parece claro, resultaría bien extraño que las encomiendas de Montesa hubieran podido sustraerse a una coyuntura adversa que, sabemos, afectó con carácter general a los diferentes reinos de España, que incidió en el Reino de Valencia de manera particular ${ }^{37}$, y que todavía debió hacerlo con intensidad especial en sus comarcas septentrionales - precisamente aquellas en que se asentaba la porción mayor y el núcleo del territorio montesiano--, que debieron añadir a los problemas comunes los concretos derivados de la guerra de Cataluña, un más que dilatado conflicto si consideramos preámbulos y flecos ${ }^{38}$. Disponemos al respecto, además, de contundentes datos sobre una variable indirecta pero estrechamente relacionada con la renta señorial: la evolución de la población. En la tabla 5 se compara, para el conjunto del señorio de Montesa, el ya clásico recuento de $1692^{39}$ con estimaciones anteriores que deben reflejar los niveles alcanzados a finales del siglo $\mathrm{XVI}^{40}$. Aun descontando el muy elevado grado de oculta-

36. La consideración de que los principales indicadores económicos presentan síntomas de recuperación en la España de la periferia algunos años antes de 1700 es lugar común entre los investigadores del período. Aunque es cierto también que la guerra que asoló en los primeros años del siglo XVIII el País Valenciano siembra dudas sobre la posible recuperación de las rentas. Sobre la coyuntura económica en el Reino de Valencia del siglo XVII, véanse las notas siguientes.

37. Véase, por todos, CASEY, J., op. cit. De confirmarse la estabilidad deberíamos, en todo caso, pensar en otro tipo de hipótesis, de imposible comprobación desde nuestras fuentes: por ejemplo, que la estimación de 1707 se refiriera a ingresos teóricos y no a ingresos reales, lo que parece improbable tratándose de arriendos.

38. Tanto sobre la evolución coyuntural (que incluye alarmantes síntomas de crisis desde el comienzo del siglo XVII) como sobre la importancia de la guerra de Cataluña para con la zona y la Orden de Montesa aporta información abundante (y no sólo respecto de sus consecuencias económicas, sino también una interesante lectura en clave política -ésta, en pp. 90-101-), la reciente tesis doctoral de HERNÁNDEZ RUANo, Javier, Justicia y sociedad en el señorio de la Orden de Montesa en los siglos XVI y XVII, Universidad de Valencia, 2004. Se hallarán allí testimonios de sequias, malas cosechas y pestes, asi como una valoración de la expulsión de los moriscos en la zona; y, sobre todo, abundantes noticias sobre la presencia y consecuencias de la guerra: alojamiento de tropas, campañas y asedios, presión fiscal, ahogo financiero de los municipios, exacerbación del bandolerismo, construcción de fortificaciones, territorio convertido en cuartel general de la contraofensiva, etc. (especialmente en pp. 252-281, 339-340, 348 349, 366-367). Son pocas, sin embargo, además de indirectas y de limitado alcance, las que se refieren a la economía de la Orden en concreto (en p. 277). Había el citado autor adelantado algunos de los materiales en «Defensa y logistica: el norte valenciano durante la Guerra de los Treinta Años», Boletin del Centro de Estudios del Maestrazgo, n. 68 (2002), pp. 15-36. Su trabajo remite además a la relativamente rica producción historiográfica local que se ha ocupado del tema, en la que cabe destacar, entre la más reciente, la monografia de FerReres I Nos, Joan, Temps de Bandolers, Bandolerisme del segle XVII a les comarques del Maestrat, Ports de Morella, Montsià i Terres de l'Ebre, Benicarló, Centro de Estudios del Maestrazgo, 2002.

39. Fue realizado a raíz de la conocida pragmática de reclutamiento de aquel año. Lo divulgó GARCíA MARTínEZ, Sebastián, Valencia bajo Carlos II, Valencia, Universidad, 1974, vol. II, pp. 217-233.

40. Eso persiguen las cifras recogidas bajo el rótulo Máximos, 1564-1624, que integra valoraciones de Viciana, Escolano y el también conocido censo de 1609. Sobre los criterios seguidos en su elaboración se informó en «La economía de la Orden de Montesa...»; y los datos de referencia pueden ahora ser también contrastados, casi todos, en Bernat i MARTí, Joan Serafi y BADENES MArtín, Miquel Àngel, 
TABLA 5. EL SEÑORÍO DE LA ORDEN DE MONTESA. POBLACIÓN. ESTIMACIONES, SIGLOS XVI - XVII

\begin{tabular}{|c|c|c|c|c|}
\hline & \multicolumn{2}{|c|}{$\begin{array}{l}\text { Estimación máxima } \\
1564 / 1609 / 1611 / 1624\end{array}$} & \multicolumn{2}{|c|}{ Censo de 1692} \\
\hline & Vecinos & Indice & Vecinos & Índice \\
\hline \multicolumn{5}{|l|}{ MAESTRAZGO } \\
\hline Bailío de Cervera & 2590 & 100 & 1529 & 59,0 \\
\hline Bailío de Moncada & 320 & 100 & 235 & 73,4 \\
\hline Bailío de Sueca & 500 & 100 & 267 & 53,4 \\
\hline Bailio de Montesa & 500 & 100 & 308 & 61,6 \\
\hline SUBTOTAL MAESTRAZGO & 3910 & 100 & 2214 & 56,6 \\
\hline \multicolumn{5}{|l|}{ ENCOMIENDAS } \\
\hline Mayor (Les Coves) & 858 & 100 & 476 & 55,5 \\
\hline Culla (Atzeneta) & 740 & 100 & 475 & 64,2 \\
\hline Benasal & 350 & 100 & 268 & 76,6 \\
\hline Ares & 170 & 100 & 196 & 115,3 \\
\hline Silla & 200 & 100 & 81 & 40,5 \\
\hline Montroy & 70 & 100 & 12 & 17,1 \\
\hline Perputxent & 170 & 100 & 124 & 72,9 \\
\hline SUBTOTAL ENCOMIENDAS & 2558 & 100 & 1632 & 63,8 \\
\hline TOTAL ORDEN & 6468 & 100 & 3846 & 59,5 \\
\hline
\end{tabular}

ción del censo de 1692, tantas veces puesto de manifiesto desde estudios locales, es evidente que la caída demográfica habría sido intensa durante el siglo y en todas y cada una de las circunscripciones analizadas, por supuesto encomiendas incluidas. Respecto de los datos encontrados para 1564-1624, la población del señorío del maestrazgo de Montesa apenas alcanzaba a fines del seiscientos el $56,6 \%$, y la de las encomiendas el $63,8 \%{ }^{41}$. Es

Crecimiento de la población valenciana. Análisis y presentación de los censos demográficos (16091857), València, Edicions Alfons el Magnànim, 1994.

41. Media aritmétrica de las siete que en la tabla figuran. Algunas de las encomiendas costeras (BenicarlóVinaròs y Alcalà), se encontraban en zonas sometidas a un régimen de reclutamiento específico por parte de la Marina, y no fueron consideradas en el censo de 1692. Tampoco incorpora la tabla información de Onda y Vilafamés, ya que ambas habían dejado de poder ser consideradas territorio de Montesa, incorporadas a la jurisdicción real en 1608 y 1673 respectivamente; se equiparaban en tal sentido a las también encomiendas sin vasallos de Burriana y Ademuz-Castielfabib; véanse al respecto «La singularidad...» y «La economía de la Orden de Montesa...». Por otra parte, la profesora Tropé proporciona en su ya citada obra (vol. I, pp. 53-54) los resultados de otro censo de población, fechado en 1646 y que procede del Archivo del Reino de Valencia, Generalitat, 5825-29. Pero he decidido no incorporar sus datos a mi tabla considerando las lagunas de esa fuente, pues no ofrece información para las villas y lugares, por 
cierto que entre éstas aparece alguna posible excepción-Ares, Benasal incluso-, pero la tónica era general, y los descensos pueden considerarse más que severos si consideramos casos como los de Montroy $-17 \%-$ o incluso Silla $-40 \%{ }^{-42}$.

$\mathrm{Y}$ ocurre sobre todo -y pasamos con ello de indicios y variables indirectas a lo que parecen ser pruebas- que la crisis sí habría afectado a las rentas de la mesa maestral, y que lo habría hecho, además, con violencia, como puede constatarse en la tabla 1 , que contrasta las ya comentadas estimaciones de la primera mitad del siglo con las dos nuevas con que por fortuna contamos para valorar el estado de las cuentas del maestrazgo de Montesa ya muy avanzado el siglo XVII, fechadas ambas, de modo circunstancial según creo, en el mismo año, en 1693.

Supone en efecto un alivio disponer, cuando menos, de dos diferentes estimaciones desde donde describir la situación de las finanzas del maestrazgo en aquellos años ${ }^{43}$; cuando conocía únicamente una, dudaba de su credibilidad, receloso de que su autor pudiera haber dramatizado adrede la situación límite que reflejaba. Lo explicaré. Procedía aquella primera valoración de un breve impreso del prolífico frey Hipólito de Samper y Gordejuela, para entonces procurador general de la Orden ${ }^{44}$, «suplicando [a Su Majestad] el alivio de la receta [recepta] Maestral, para que no se le impongan nuevas cargas quando oy no se halla con caudal para mantener las antiguas $\rangle^{45}$. El asunto tratado en el memorial era en el fondo menor: si correspondía a las arcas reales o a las del maestrazgo de Montesa sufragar el salario de un oficial -el «oficial mayor» de la

ejemplo, de Vallada (bailío de Montesa), o Les Coves de Vinromà, Salzadella y Tirig (todas ellas de la «encomienda mayor»), pudiendo en consecuencia dar lugar a problemas contables.

42. Más evidencias sobre la crisis demográfica en el País Valenciano del siglo XVII, en ARDIT LUCAS, M., op. cit., pp. 43-48; y sobre su incidencia en concreto en las comarcas septentrionales, en HERNÁNDEZ RUANo, J., Justicia y sociedad.., cit., pp. 304-310. Pero, sobre todo, en BERnAT I MARTí, J. S., BADENES MARTIN, M. Ȧ., op. cit.; por cierto: incorpora también esa oportuna recopilación de censos el vecindario de 1646 (pp. 32-33 y 173-191), que arroja, a grandes rasgos (y mayor precisión está fuera de lugar en un estudio como el presente) resultados ya próximos a los de 1692 , si bien en bastantes de las más importantes circunscripciones la pérdida de población fue todavía a incrementarse, como era esperable, entre los dos recuentos; lo que no entra en contradicción con otros indicios que anuncian el inicio de una cierta recuperación desde las últimas décadas del seiscientos.

43. Disponemos de tres en realidad si consideramos la escueta referencia con que hemos abierto estas páginas. Todavía más noticias podría proporcionar una explotación completa del manuscrito $n^{\circ} 2688$ de la Biblioteca Nacional, donde se conservan otras estimaciones, que ya no he creído necesario explorar a fondo -sí lo he hecho superficialmente- por considerar que poco podrían aportar a la información que es posible obtener desde las fuentes aquí efectivamente utilizadas.

44. Religioso montesiano y autor, entre otras obras, de la bien conocida Montesa Ilustrada. Origen, fundación, principios, institutos, casos, progresos, jurisdicción, derechos, privilegios, preeminencias, dignidades, oficios, beneficios, héroes y varones ilustres de la Real, inclyta y nobilissima Religión Militar de $N$. S. Santa Maria de Montesa y San George de Alfama, Valencia, Gerónymo Vilagrasa, 1669, 2 vols.

45. SAMPER y GORdejuela, frey Hipólito de, Al Rey Nuestro Señor. Memorial que pone a sus Reales pies frey don Hypólito de Samper y Gordejuela, Procurador General de su orden de Montesa, suplicando el alivio de la receta Maestral, para que no se le impongan nuevas cargas, quando oy no se halla con caudal para mantener las antiguas, Madrid, sin impresor, 1693, fol., 12 hojas (un ejemplar, en BN, Varios Especiales, sign. 69/19). 
secretaría de Montesa en el Consejo de Aragón-, de apenas 3.000 reales al año. Y en ello precisamente sustentaba el religioso sus tesis: «y quando este corto gasto ocasiona tal horror, qué tal será la angustia de la Orden». Sostenía, en efecto, que «hoy, de los 18000 teóricos [ducados de renta del maestrazgo ${ }^{46}$ ] entran no llega a $8000^{47}$, siendo necessarios para los gastos precissos [alimentos del convento y colegio y «tenues» salarios de los empleos de la Orden -adviértase la sutileza de quien se considera mal pagado para introducir su opinión al respecto-] 9000 ducados». Estimaba así un déficit anual mínimo de 1.500 ducados que, al arrastrarse ya durante algunos años, habría llevado a la acumulación de atrasos, que se comentan más adelante. Aprovechaba frey Hipólito, por cierto, para recordar al rey los «favores» que desde la Orden había recibido, como cuando desde el maestrazgo se habrían sufragado parte de los salarios de los ministros del Consejo de Aragón, o cuando se habían exigido imposiciones especiales en el territorio de la Orden para contribuir a los gastos de mantenimiento del ejército real en Cataluña ${ }^{48}$. En realidad, lo que Samper hacía era reivindicar en su conjunto una supuesta deuda histórica que la monarquía habría contraído con la Orden de Montesa desde el momento de la incorporación, por importe de las cantidades que obtenidas desde la explotación del señorío de la institución no se habían utilizado en gastos relacionados con Montesa de manera directa, y que evaluaba, para el período comprendido entre 1595 y 1650 , en la nada despreciable suma de 624.350 reales (unos 60.000 duca$\operatorname{dos}^{49}$ ). Por último, el clérigo montesiano utilizaba también la oportunidad para criticar con acidez la etapa en que la gestión de las finanzas de la Orden había sido puesta en

46. Ahí sí hubo seguro un punto de exageración, pues nunca había alcanzado la renta de la mesa maestral de Montesa tal recaudación, según hemos podido comprobar (véase «La economía de la Orden de Montesa...»). En fin, siendo su objetivo -que lo era- dramatizar su presente (1693) resultaba lógico que exagerara (tampoco lo hizo demasiado) el anterior esplendor.

47. Estimación que hemos llevado a la tabla 1 convertida en libras a razón de 1 ducado $=2$ I sueldos $(8.400$ libras); vease, no obstante, la nota 7.

48. Los pagos de los salarios habrian tenido lugar, según comenta el propio Samper, entre 1630 y 1650 . En cuanto al dinero para el ejército de Cataluña, conocemos una única contribución, por lo demás relativamente modesta (1.634 libras), que se habría realizado en 1676, gestionada por oficiales de la Orden: RAH, CSC, sign. 9/616, ff. 91-104. Véase la nota 38.

49. Adjuntaba el impreso una «Memoria de las cantidades que los reyes nuestros señores han mandado sacar de su receta maestral para subvenir las urgencias (contiene lo gastado por los Reyes a su arbitrio y lo mandado por la Orden al Consejo de Aragón, hasta un total de 624350 reales entre 1595 y 1650)». Se trata, en cualquier caso, de una cantidad verosímil habida cuenta los superávit obtenidos tradicionalmente de la administración del maestrazgo (véase «La economía de la Orden de Montesa...»). Supongo que incluía los antes citados salarios pagados a ministros del de Aragón y la contribución para el ejército de Cataluña, aunque el detalle no sea relevante, y desconozco también si merecen para Samper la calificación de deudas a Montesa las pensiones otorgadas por los monarcas a personas sobre la renta de la Orden y que en su mayor parte recaían en individuos vinculados al instituto; supongo, en este caso, que no. De otra parte, para los escribanos del Consejo de Aragón, 10 reales equivalían en aquel momento -fines del siglo XVII- a una libra valenciana (véase BN, $m s . n^{\circ} 2688$, ff. 104-109). Aunque, ciertamente, las alteraciones que en la época sufrió la moneda castellana-veremos después reflejos concretos de ese problema- obligan a observar cautela en cualquiera de las conversiones monetarias que se realicen. 
manos de instancias ajenas al instituto, en concreto de la Junta Patrimonial del Reino de Valencia ${ }^{50}$.

Con tales contenidos, el memorial debe ser interpretado en clave política ${ }^{51}$, obligando el tono y las intenciones del discurso de Samper a la prevención, por mucho que el informe parezca riguroso en la apreciación de la crisis económica del maestrazgo ${ }^{52}$, que achacaba a «la guerra de Cataluña y la peste».

La prevención era, sin embargo, injustificada: los problemas financieros existían, y parecían tener, poco más o menos, la intensidad que Samper les confería; a su particular cosecha sólo cabría atribuir lo apocalíptico del estilo. Los datos de una estimación archivística del mismo año de $1693^{53}$, de la que no parece pueda haber motivos para dudar, resultan del todo coincidentes con los del procurador de Montesa, y tanto en lo que se refiere al ingreso como al gasto; y su detalle (véanse las tablas 1, 3 y 4) nos permite además apreciar mejor lo ocurrido.

El ingreso se había desplomado hasta alcanzar tan sólo unas 8.200 libras valencianas en aquel año: es decir, apenas suponía el 52\% del supuestamente registrado en 1624. Y el desastre se debía, habiéndose mantenido los niveles de las «responsiones» de encomiendas y villas, y hasta acrecentado el apartado de otros ingresos varios, al desmoronamiento -sin excepción- de las rentas procedentes de los arrendamientos de los derechos señoriales en los bailíos: se situaban ahora, en relación a las cotas que habían alcanzado en 1632-33 (última estimación pormenorizada de que disponemos, la de Beltrán), entre el 88,9\% (en Moncada, el bailío menos afectado) y... ¡el 55,7\%! (Cervera); las circunscripciones más afectadas eran ésta última y Sueca, las columnas vertebrales de la renta del maestrazgo ${ }^{54}$, y lo eran en proporciones parejas ${ }^{55}$. En fin: también los ingresos derivados de «penas y calonias» se encontraban bajo mínimos:

50. Véase «La singularidad...», p. 553.

51. He apuntado en otro lugar (en concreto en el artículo citado en la nota anterior) la existencia de un significado grupo de miembros del instituto que, en la segunda mitad del siglo XVIL, practicó con cierto éxito lo que vine a llamar montesianismo militante, tendente en lo esencial a reivindicar los derechos de la propia Orden a autogobernarse, cuestionando la medida en que la incorporación suponía dependencia del administrador perpetuo por encima de la original obediencia directa de Montesa -como de todas las órdenes- a Roma. Samper debió pertenecer a aquel grupo de montesianos.

52. Lo acompañaba Samper, también, de sendos informes en el mismo sentido, uno de Juan Pertusa Bonastre, «bayle de Moncada y receptor de la Mesa Maestral», y otro del lugarteniente general, Conde de Cardona, fechados ambos en 6 de enero de 1693.

53. BN, Manuscritos, $\mathrm{n}^{\circ} 2688$, exp. 24, ff. 104 y ss. Informe sin firma elevado al Consejo de Aragón.

54. Lo habían sido a finales del siglo XVI (véase «La economía de la Orden de Montesa...»), seguían pese a todo registrando los mayores ingresos, y continuarian haciéndolo en el siglo XVIII: véase al respecto SÁNCHEZ DURÁ, M. " D., op. cit.

55 . Sueca, 59,8\%; en un término medio, la renta del bailío de Montesa se situaba en el $77,2 \%$ de la obtenida cuando fue valorada por frey Miguel Beltrán. 
«lo que procede de la jurisdicción es tan incierto que en 10 años no se han sacado 160 libras, y en los más no se saca un real» ${ }^{56}$.

La reducción del ingreso no se habría visto además acompañada de un descenso de los gastos corrientes (tabla 3), cuyas principales partidas presentaban según parece fuertes resistencias a los recortes. En el caso de los gastos del convento y del colegio de San Jorge, la nómina de 46 comensales, que se habría mantenido ya más o menos estable desde la época de frey Joan Borja y frey Miguel Beltrán, no parecía permitir alegrías. No obstante, la estimación de 1693 arañaba en los «alimentos» hasta el último dinero de la última ración del último criado, con lo que lograba que ese apartado, con apenas 1.500 libras anuales, se viera reducido prácticamente a la mitad. Pero era el único: vestuario, limosnas, gastos conventuales extraordinarios, gastos médicos y otros conceptos antes siquiera considerados se empeñaban en mantenerlo por encima de las 5.000 libras anuales, incluso un poco más elevados que en las valoraciones de 1624 y $1632-33^{57}$.

Y lo mismo cabe decir de los salarios, también algo incrementados incluso en su montante global respecto de la peritación de Borja, e inferiores tan sólo en unos pocos cientos de libras si la referencia es la de Beltrán. No se había llevado a efecto, por tanto, una política de austeridad en los órganos de la administración de la Orden. Hay sin embargo en este mismo apartado, además, un aspecto que llama poderosamente la atención: la estructura espacial de los salarios se había visto alterada por completo. Sí se había visto reducida, y bastante -en un 50\%-, la partida destinada a los salarios a pagar en el señorío de la Orden ${ }^{58}$. Y aparecía también adelgazada -al menos sobre el papel, y aunque muy poco- la comprometida a los destinados a Madrid, sobre los que

56. BN, ms. n² 2688, exp. 24, f. 104, de la misma estimación de 1693; de hecho, la documentación utilizada no las consideraba a efectos contables, ofreciendo una renta total anual de 8.197 libras, a la que nosotros hemos añadido otras 16 libras del promedio resultante para dicho concepto (véase tabla 1).

57. Todavía hubo, además, otro gasto ciertamente excepcional para el que se consideró imprescindible establecer una fórmula de financiación alternativa: había sido sólo unos pocos años antes (hacia 1670-72) que se labró el nuevo coro de madera del convento por estar el antiguo «dirruydo de tantos años ha que sirve». Desde luego, como declaró el lugarteniente general -quien propuso la renovación-, «no havía effetos de dinero en la Orden para hacer dicha obra», por lo que debió ser sufragado con limosnas extraordinarias de caballeros y religiosos de la institución y de algunos pueblos del señorio. Costó casi 2.500 libras. Debo la noticia, la referencia de la documentación que la contiene (ARV, Clero, Cajas 22702271) y las expresiones textuales a Josep Cerdà i Ballester.

58. Es cierto que la caída se debe fundamentalmente a la desaparición de los costosos salarios de tres de los cuatro «bailes», sobre los que algo habíamos dicho con anterioridad y que podrían haberse dejado de abonar. En cualquier caso, resulta interesante comprobar que la cuota de participación de los salarios del territorio señorial sobre los totales experimentó un descenso constante y acentuado desde las primeras estimaciones: $100 \%$ en 1592, 75\% en 1593 (véase «La economía de la Orden de Montesa...»), 56\% en $1602,51 \%$ en 1624 (Borja), 48\% en 1632 (Beltrán), 21\% ahora. El aparato administrativo del territorio no se desarrolló apenas tras la incorporación, centralizándose la dirección del instituto en Madrid y en Valencia, donde sí se fueron creando nuevos cargos. 
cabría hacer algunas apreciaciones, tanto en términos generales ${ }^{59}$ como, en concreto, a los que correspondían al secretario del Consejo de Aragón ${ }^{60}$ y a los desaparecidos capellanes del rey ${ }^{61}$. En cualquier caso, se desvela así lo fundamental del cambio: la administración de la Orden en la ciudad de Valencia, hasta 1624 mínima -recibía el $4,8 \%$ del montante total de los salarios en aquella fecha- había crecido con generosidad, hasta alcanzar ahora el $43 \%$. El lugarteniente general recibía ya un salario (lo hacía ya en 1632), y su corte se veía ampliada con varios nuevos cargos remunerados: receptor, procurador general, secretario, escribano y alcalde del palacio del Temple ${ }^{62}$. Venía a añadirse el también reciente ingreso en nómina del maestre racional, encargado ahora de supervisar las cuentas que debía presentarle el receptor de Montesa. Y, por último, resulta que a la altura de 1693, agobiado el maestrazgo, los gastos de representación de Montesa, sus obligaciones sociales, se habian incrementado, debiendo sufragar el importe de diversas fiestas con sus luminarias y toros en Madrid y Valencia por un importe nada despreciable.

Con todo ello, y con una previsión de gasto anual en obras de 500 libras, muy inferior al estimado por Beltrán, el gasto general ordinario ascendía en 1693 (véase la tabla 4) a 9.742 libras, frente a las 8.066 de 1624 (es decir, era un $20,7 \%$ superior), y se situaba sólo un 10\% por debajo del calculado por Beltrán en 1632-33, el máximo de entre nuestras estimaciones en la historia de Montesa.

Estables los dispendios conventuales y los salarios, y acrecentado el gasto suntuario y otros conceptos varios, el intento obligado de acompasar el gasto total a la menguante evolución del ingreso había elegido como imprescindibles víctimas a todos y cada uno de los beneficiarios de las pensiones a que venía obligado el maestrazgo de Montesa, cuyo pago se había sencillamente suspendido en un $100 \%$ de orden del maestre racional ${ }^{63}$. Y todavía así, el desfase de 1.500 libras anuales que presentaba

59. Los salarios a satisfacer en Madrid se expresan, como todos, en libras valencianas. Pero llevan aparejado un incremento, que también recoge ya la documentación (y las tablas) en la valoración tinal, «por el interés de reducir esta cantidad a plata» (BN, $m s, n^{\circ} 2688$, ff. 104-109), que resulta ser de un $20 \%$. Son secuelas de los graves problemas monetarios de las últimas décadas del siglo, que igualmente se reflejaban en las cuentas del convento, que incluían en 1693 (véase la tabla 3) un antes inexistente apartado de «intereses, trueques y portes de dinero».

60. Era ese el oficio cuyo salario habia provocado el ya comentado memorial de Samper. Llama la atención la remuneración, sólo 185 libras (más el premio), cuando eran 300 (los 3.000 reales disputados) en las valoraciones de Borja, Beltrán y del propio Samper. Posiblemente, su importe se habría prorrateado entre las arcas de Montesa y las de la Corona, o simplemente se le había disminuido la asignación.

61. En realidad, la caida de los salarios de Madrid es efecto, casi exclusivamente, de la no inclusión en las cuentas de estos dos empleos. Desconocemos las causas que lo motivaron, posiblemente relacionadas con la urgencia extrema de la situación, porque es difícil pensar en la extinción de los beneficios y sus salarios. De hecho, hacia aquellos mismos años, un documento de puño y letra de Samper (se cita completo más adelante, en la nota 71) daba cuenta de su existencia, valorándolos además en nada menos que 652 libras anuales en su conjunto.

62. No es posible, por supuesto, dejar de poner en relación tales hechos con el movimiento al que se ha hecho alusión en nota 51 .

63. BN, ms. n² 2688, ff. 104-109. 
la renta respecto de los gastos considerados inexcusables, del que también había ya hablado Samper y que reproducía casi idéntico la estimación de 1693 (véase otra vez la tabla 4), había hecho que los atrasos se fueran acumulando también en ese apartado. Alcanzaban para entonces las 10.943 libras, 2 sueldos y 11 dineros. No era, si se quiere, demasiado, apenas lo correspondiente a un año y medio del ingreso del maestrazgo. Aunque claro, todo dependía del punto de vista desde el que se mirase: porque a los ministros y oficiales, es decir, a los empleos de la orden -y entre ellos, por tanto, al propio Samper, que era quien esto denunciaba-se adeudaban hasta « 10,11 y 12 tercias» o, lo que es lo mismo, hasta cuatro años de salario ${ }^{64}$. La situación debió ser muy delicada: no se pagaban las mercedes concedidas por los reyes, los sueldos presentaban atrasos, se acumulaba deuda... De ello, y como última pincelada, podrían dar idea unas pocas iniciativas que aquel estado de cosas habría propiciado.

Algunas de ellas se gestaron en el Consejo de Aragón, y se tradujeron en reales disposiciones. Sabemos por ejemplo que desde al menos 1678, y en lugar de cederlas al «tesoro» de la orden como mandaba una antigua disposición capitular, el rey tenía secuestradas las rentas de las encomiendas «vacantes» para aplicarlas «al desempeño de la receta maestral 1$\rangle^{65}$. Algunos años después se postergaba durante un año entero más el nombramiento de nuevos comendadores para incrementar los ingresos así obtenidos con el mismo fin: «he venido a conceder un año de mortuorio en las vacantes de todas las encomiendas [...] comenzando desde el primero dia del mes de junio siguiente a la muerte del comendador; pues hasta entonces ya la vacante es, por definición, de la receta $\rangle^{66}$. En aquel mismo despacho, y también con el pretexto de aliviar el maestrazgo, se suprimía el oficio de subclavero, cuyas obligaciones pasaban a ser desempeñadas por el subcomendador, aunque la medida suscitó protestas y debió tramitarse en Roma, que concedió, según creo, permiso sólo temporal ${ }^{67}$.

Y se debieron otras propuestas a la inagotable actividad de frey Hipólito, con un carácter común que cabría calificar, cuando menos, de extraordinario, aunque lo fuera por motivos diversos. Referiremos tres.

Una de ellas trataba de descargar a la Orden de antiguas obligaciones. En 1683 solicitaba Samper «la exempción de subsidio y excusado, con que se le aumentan [al maestrazgo] quinientas libras de renta, pues la orden no deve pagar esta contribución, como no la pagan las órdenes militares de Castilla, porque lo contrario sería pagar V. M. a sí mismo, como V. M. se sirvió resolverlo el año 1594 a consulta del Consejo» ${ }^{68}$.

64. SAmper y Gordejuela, Hipólito, Al Rey Nuestro Señor. Memorial..., cit.

65. Databa la disposición del capítulo de 1588 , y fue fruto de las maniobras últimas del maestre Galcerán y bastante dolorosa al maestrazgo (véase «Política y economía en el Consejo de Aragón...»). El documento que la anulaba, en RAH, CSC, sign. 9/576, f. 120, Real Orden de 5 de enero de 1678.

66. BN, $m s . n^{\circ} 2731$, exp. 20, f. 29 r, 1691.

67. Por sólo seis años; ibídem.

68. RAH, CSC, sign. 9/624, f. 140, 7 de octubre de 1683, informe del Consejo de Aragón (Samper actuó como procurador general de la Orden) al Rey. 
Más allá de la petición y de su, en apariencia, incontestable lógica ${ }^{69}$, la demanda produce una cierta sorpresa, porque -lo recuerdo- las relaciones de gastos de que disponemos nunca habían contabilizado tales partidas, por lo que dudamos que hubieran sido satisfechas con regularidad.

La segunda parecía un tanto más lógica: llegó a proponer frey Hipólito que todas y cada una de las «dignidades, beneficios y oficios» de la Orden con dotación superior a los trescientos reales anuales de renta -es decir, casi todos, incluidos los paniagua$d o s^{70}$, renunciaran a una tercera parte de sus ingresos durante algunos años en vista de la delicada situación económica que conocía el maestrazgo ${ }^{71}$. Confeccionó para ello un listado, del que podría deducirse que el ahorro así obtenido podría haber alcanzado unas 1.700 libras anuales, de las que 1.100 habrían correspondido a «empleos» que recibían sus honorarios directamente desde el maestrazgo, siendo las restantes 600 libras contribuciones que algunos religiosos - priores y rectores- podrían hacer a la Orden desde sus propias fuentes de ingresos. Que sepamos, la proposición nunca se llevó a efecto.

Por fin, el religioso montesiano realizó asimismo un estudio sobre «lo que pagan los cavalleros de las Órdenes Militares de Castilla para tomar el hávito de ellas», y lo comparó con el coste que tenía en Montesa ${ }^{72}$; como quiera que resultaba mucho más económico en esta última (tan sólo 5.040 reales frente a 9.240 de media en las órdenes castellanas), propugnó su incremento. Pretendía con ello, creo que otra vez sin éxito, subvenir necesidades puntuales; pero, en cualquier caso, y como en las propuestas anteriores, sus palabras transmiten una muy seria impresión de acuciante precariedad ${ }^{73}$.

De todos modos -y es esto ya tan sólo anécdota- tampoco debe extrañarnos que muchas de las propuestas del incansable frey Hipólito acabaran en saco roto. Porque,

69. Más todavía desde el punto de vista de lo que fue la práctica del montesianismo militante, que, si por un lado intentaba limitar la capacidad de acción del monarca sobre el instituto, no dudaba por otro en asirse a las ventajas que para la Orden pudiera ofrecer la condición del rey como «administrador perpetuo» (véase «La singularidad...»).

70. Caballeros que, en espera de acceder a una encomienda, recibian una magra asignación con cargo bien a la mesa maestral, bien a las encomiendas mejor dotadas (véase Breve resolución, Primera Parte, cap. 19).

71. RAH, CSC, sign. $9 / 624$, f. 243 , sin fecha (fines del siglo XVII): «Arancel del valor de las dignidades, beneficios y oficios de la Orden de Montesa, sin las encomiendas y otros beneficios y oficios que no pasan de trescientos reales de renta». La estimación de los salarios que hacía Samper en este informe es prácticamente idéntica a la que ya hemos visto para 1693, por lo que eludimos detallarla; lo mismo ocurre con otra fechada años después (1707), correspondiente al también ya citado informe de Pasqual Sala a Felipe V.

72. RAH, CSC, sign. 9/624, fols. 233-234, sin fecha (finales del siglo XVII).

73. «Y por cuanto no hay archivo decente en el convento, ni caxones, armarios, bufetes, sillas, tinteros, papel, y libros para registrar; ni archivero que lo haga, y no puede conservarse la Orden sin todo esto, parece que para mientras se fabrique el archivo y se componga de lo necesario, se podrían imponer 300 reales de plata sobre cada caballero que tome el ábito para este efecto [...] y después de fabricado y compuesto se saque deste efecto para su conservación y para un salario competente al archivero, que parece lo será de 50 libras» (ibidem). 
a menudo, cuando hablaba de dineros, proponía no sólo la fuente, sino también el destino, que no solía serle ajeno: hacia las mismas fechas propugnó también la creación de un nuevo «tesoro» de la Orden en Madrid que debería haberse sufragado con rentas de «vacantes» de prioratos, beneficios y oficios -las «vacantes» de las encomiendas debían continuar siendo para el tesoro de Valencia-. El motivo aducido era la necesidad de subvenir necesidades como la que, por ejemplo, se había presentado poco tiempo atrás con motivo del conocido episodio del encarcelamiento en la Corte del caballero montesiano Ros de Ursinos ${ }^{74}$. Arguyó que el asunto había supuesto a la Orden gastos por importe de 3.830 reales y medio. Y el problema para Samper era que la Orden había sido, para el caso, él mismo ${ }^{75}$.

74. Véase MOlas RibalTA, Pere, «Montesa ilustrada, Montesa defendida», en Les Ordes Equestres, militars y maritims i les marines menors de la Mediterrània durant els segles XIII-XVIII (Jornades d'estudi), Barcelona, Publicacions de la Universitat, 1989, pp. 55-63. Se trató de un típico conflicto por la jurisdicción sobre personas entre las justicias ordinaria y de la Orden, en el que acabaría imponiéndose esta última.

75. RAH, CSC, sign. 9/624, f. 244 (Gastos hechos en Madrid por el proceso de Dionisio Ros de Ursinos. Informe de frey Hipólito de Samper). Aunque, procediendo de quien procede, la información no debe considerarse fehaciente sin más: anduvo siempre Samper preocupado por sus ingresos; pidió una y otra vez recompensas por los servicios prestados: puede consultarse al respecto ANDRÉS ROBRES, F., «Textos publicados en torno a Montesa en los siglos XVI, XVII y XVIII y edición de manuscritos: historiografia clásica y fuentes impresas de la orden militar valenciana», en Las Ordenes Militares en la Península Ibérica. Vol. II: Edad Moderna (J. López-Salazar Pérez, coord.), Cuenca, Ediciones de la Universidad de Castilla-La Mancha, 2000, pp. 1289-1314, notas 53 y 54 (los documentos de referencia, en BN, Varios Especiales, 209/141; y RAH, CSC, sign. 9/616, pp. 272-274 y 284-287; y sign. 9/623, pp. 157-158 y 147-148); y se las ingenió otras veces para asegurarse fuentes de ingresos alternativos a los que le proporcionaba la Orden, como cuando intentó relanzar la centenaria y entonces en decadencia Cofradía de San Jorge (información, por ejemplo, en RAH, CSC, sign. 9/1545, carpeta 19, exps. 2 y 12). 